\title{
Response of LED lights intensity on lettuce production in a home vertical farm
}

Respuesta de la intensidad de luces LED sobre la producción de lechuga en una granja vertical casera

Resposta da intensidade da luz es LED na produção de alface em uma fazenda doméstica vertical

Daniel Fuentes Morales ${ }^{1}$

Jorge Flores Velázquez ${ }^{2 *}$

Ariosto Aguilar Chávez ${ }^{3}$

Rodrigo Roblero Hidalgo

Rev. Fac. Agron. (LUZ). 2022, 39(1): e223920

ISSN 2477-9407

DOI: https://doi.org/10.47280/RevFacAgron(LUZ).v39.n1.20

\section{Crop Production}

Associate editor: Dr. Jorge Vilchez-Perozo
${ }^{1}$ Posgrado en Ciencias del Agua, Instituto Mexicano de Tecnología del Agua, Jiutepec, Morelos, México.

${ }^{2}$ Colegio de Postgraduados, Campus Montecillo, Montecillo, Texcoco, Estado de México, México.

${ }^{3}$ Instituto Mexicano de Tecnología del Agua, Jiutepec, Morelos, México.

Received: 19-01-2021

Accepted: 24-05-2021

Published: 26-02-2022

\section{Keywords:}

Hydroponics

Photoperiod

Urban agriculture

Fresh weight

\begin{abstract}
There are several LED lamps on the market that were not designed to produce lettuce; however, they can be purchased at a low cost. In Mexico there is a lack of research on its use in small-scale vertical farms with hydroponics established in urban agriculture. The objective of this work was to measure the response of three commercial lamps with LED lights on the growth and morphogenesis of sangria lettuce grown in a lowcost home vertical farm. The sangria lettuce was subjected to three light intensities with different spectra and photoperiod. After 30 days of growth the plant height, leaf length, leaf width, number of leaves and fresh weight were measured, with these measurements a one-way analysis of variance (ANOVA) was performed and Duncan's multiple comparison method was used through an algorithm designed in Python. According to the results, the highest fresh weight was observed for a light intensity of 5700 lux. In the 2100 lux treatment, the highest height of the plant was observed and it was the treatment with the highest energy consumption. The production of lettuce at home is technically feasible, however, in addition to the light intensity, it is necessary to evaluate the quality (wavelengths) from the agronomic point of view.
\end{abstract}




\section{2-5 | Rev. Fac. Agron. (LUZ). 2022, 39(1): e223920. January - March. ISSN 2477-9407.}

\section{Resumen}

En el mercado existen diversas lámparas LED que no fueron diseñadas para producir lechuga, sin embargo, se pueden adquirir a un bajo costo. En México se carece de investigaciones sobre su uso en granjas verticales de pequeña escala con hidroponía establecidas en agricultura urbana. El objetivo de este trabajo fue medir la respuesta de tres lámparas comerciales con luces LED sobre el crecimiento y morfogénesis de lechuga sangría cultivada en una granja vertical casera instrumentada a bajo costo. La lechuga sangría se sometió a tres intensidades de luz con diferentes espectros y fotoperiodo. después de 30 días de crecimiento se midió la altura de la planta, largo de la hoja, ancho de la hoja, numero de hojas y peso fresco, con dichas mediciones se realizó un análisis de varianza unidireccional (ANOVA) y se empleó el método de comparación múltiple de Duncan mediante un algoritmo diseñado en Python. De acuerdo a los resultados el mayor peso fresco se observó para una intensidad de luz de 5700 luxes. En el tratamiento de 2100 luxes se observó la mayor altura de la planta y fue el tratamiento con mayor consumo energético. La producción de lechuga en casa es técnicamente viable, sin embargo, además de la intensidad de luz se requiere evaluar la calidad (longitudes de onda) desde el punto de vista agronómico.

Palabras clave: Hidroponía, fotoperiodo, agricultura urbana, peso fresco.

\section{Resumo}

No mercado existem várias lâmpadas LED que não foram projetadas para produzir alface, porém, podem ser adquiridas a baixo custo. No México faltam pesquisas sobre sua utilização em fazendas verticais para produzir alface em climas quentes. O objetivo deste trabalho foi medir a resposta de três lâmpadas comerciais com LED no crescimento e morfogênese da alface sangria cultivada em uma fazenda vertical residencial de baixo custo. A alface sangria foi submetida a três intensidades de luz com diferentes espectros e após 30 dias de crescimento foram medidos a altura da planta, comprimento da folha, largura da folha, número de folhas e massa fresca, com medições, uma análise de variância (ANOVA) unilateral foi realizada e o método de comparação múltipla de Duncan usando Python foi usado. O maior peso fresco foi observado para uma intensidade de luz de 5700 lux. No tratamento de 2100 lux, foi observada a maior altura de planta e foi o tratamento com maior consumo de energia. Cabeças mais soltas desenvolvidas devido à temperatura do edifício. A produção de alface em casa é tecnicamente viável, porém, além da intensidade da luz, é necessário avaliar a qualidade (comprimentos de onda) do ponto de vista agronômico.

Palavras chave: Hidroponia, fotoperíodo, agricultura urbana, peso fresco.

\section{Introduction}

It is estimated that by $2050,70 \%$ of the world's population will live in urban areas and will increase from 7 billion people to more than 9 billion (OECD, 2012), requiring approximately $50 \%$ more food (Pinstrup-Andersen, 2018). In Mexico, the population is expected to reach 150.8 million people (Anda and Shear, 2017). The use of urban vertical farms has been proposed to meet the growing demand for food by making efficient use of resources (Pinstrup-Andersen, 2018; Benke and Tomkins, 2017; Beacham et al., 2019).

Vertical farms consume up to $97 \%$ less water during a year compared to traditional agriculture, due to the use of hydroponic systems and microclimate control inside the buildings, allowing to reduce evapotranspiration (Kalantari et al., 2018). Producing crops vertically allows to obtain a higher yield by making an efficient use of soil (Eigenbrod and Gruda, 2015). The use of LED lights allows food to be grown in warehouses, buildings and houses, contributing to the non-deforestation of new areas for food production (Kalantari et al., 2018).

Lettuce is one of the vegetables that, due to its agronomic requirements is most cultivated in systems under disruptive technologies in urban agriculture or indoor (Specht et al., 2014). For its production in vertical farms, it is necessary to find the intensity, luminous spectrum and photoperiod of LED lights that allow to obtain the maximum yield with the minimum energy consumption (Loconsole et al., 2019). Zhang et al. (2018) recommend using a light intensity of $250 \mu \mathrm{mol} . \mathrm{m}^{-2} \cdot \mathrm{s}^{-1}$ PPFD (Photosynthetic photon flux density) with a photoperiod of $16 / 8 \mathrm{~h}^{-\mathrm{d}^{-1}}$ (light/dark), according to the growth and energy consumption of LED lights used in their study of purple leaf lettuce (Lactuca sativa L. cv. Ziwei). In another study the best growth was obtained with a light intensity of $290 \mu \mathrm{mol} \cdot \mathrm{m}^{-2} \cdot \mathrm{s}^{-1}$ PPFD and a photoperiod of $6 / 2 \mathrm{~h}^{-d^{-1}}$, for lower light intensities, the best growth was observed with the combination of $230 \mu \mathrm{mol} . \mathrm{m}^{-2} . \mathrm{s}^{-1}$ PPFD and the photoperiods of $18 / 6$ h.d $\mathrm{d}^{-1}$ and $9 / 3 \mathrm{~h} \cdot \mathrm{d}^{-1}$ (Kang et al., 2013).

Another important factor that influences the development of lettuce is the air temperature, being a cold season crop, if it is exposed to high temperatures, biomass accumulation is reduced, stem elongation occurs and looser heads develop, if the temperature is not reduced, bolting and emission of floral stem will be caused (Alsaid et al., 2018). During the germination, the optimal temperature is from $15{ }^{\circ} \mathrm{C}$ to $20{ }^{\circ} \mathrm{C}$ (Resh, 2013). After transplanting, optimal temperatures vary from 17 to $28^{\circ} \mathrm{C}$ during the day and from 3 to 12 ${ }^{\circ} \mathrm{C}$ at night (Wurr et al., 1992).

There are several LED lamps on the market that were not designed to cultivate lettuce, however, they can be purchased at a low cost, in Mexico there is a lack of research about its use in small-scale vertical farms in warm weather. The objective of this study was to optimize the LED light according to growth and morphogenesis of sangria lettuce caused by different commercial lamps in a low-cost instrumented vertical farm.

\section{Materials and methods}

\section{Experiment description}

A vertical farm prototype consisting of a 5-level shelf (Length $\mathrm{x}$ width $\times$ height, $40.4 \times 90.4 \times 183.6 \mathrm{~cm}$ ) was acquired. It was equipped with a floating root hydroponic system made up of $39 \mathrm{~L}$ plastic tanks with 1" polystyrene plates and 2" hydroponic baskets. For oxygenation, it had an aeration system composed of $80 \mathrm{~L}$ air pumps (1588, Aquakril, Mexico) and flexible translucent silicone hose with air diffusers. Each level had 6" 117 VAC fans with $14 \mathrm{~W}$ of power (Steren, Mexico) to extract the hot air from the LED lamps (figure 1). 
Fuentes et al. Rev. Fac. Agron. (LUZ). 2022, 39(1): e223920

Sensors were also installed to monitor climatic variables (table 1) and an Arduino-based automation system to operate the illumination, ventilation and oxygenation system.

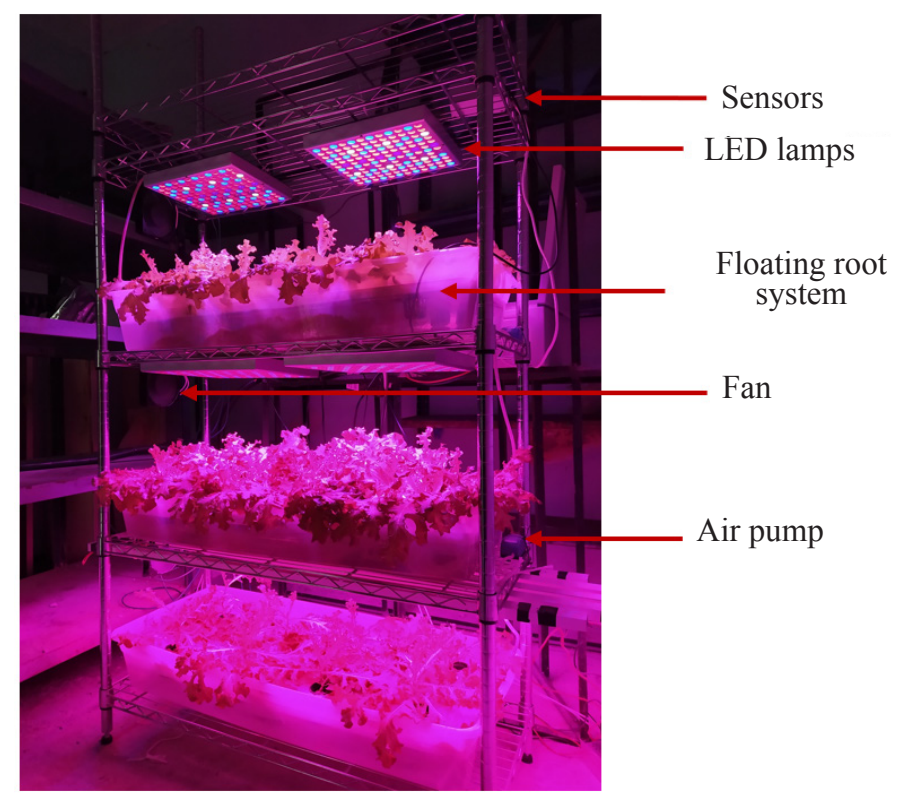

Figure 1. Characteristics of the vertical home farm with management and monitoring subsystems and sangria lettuce in production.

Table 1. Sensors for monitoring and control of the vertical farm.

\begin{tabular}{|c|c|c|}
\hline Sensor & Variable & Accuracy \\
\hline $\begin{array}{l}\text { Dht22 (UNIT Electronics, } \\
\text { CDMX, Mexico) }\end{array}$ & $\begin{array}{l}\text { Ambient temperature } \\
\text { and humidity }\end{array}$ & $\begin{array}{l} \pm 0.5^{\circ} \mathrm{C} \\
\pm 3.5 \%\end{array}$ \\
\hline $\begin{array}{l}\text { Dsb1820 (UNIT Electronics, } \\
\text { CDMX, Mexico) }\end{array}$ & Solution temperature & $\pm 0.5^{\circ} \mathrm{C}$ \\
\hline $\begin{array}{l}\text { BH1750 (UNIT Electronics, } \\
\text { CDMX, Mexico) }\end{array}$ & Light intensity & $\pm 0.5 \mathrm{~lx}$ \\
\hline $\begin{array}{l}\text { DS3231 (UNIT Electronics, } \\
\text { CDMX, Mexico) }\end{array}$ & Date and hour & 172 ms.day $^{-1}$ \\
\hline
\end{tabular}

The study was carried out inside a building located in Morelos, Mexico, built with blocks and cement, which are typical materials of the region. Sangria lettuce seeds (Lactuca sativa L.) were germinated in 144-cavity agricultural foam tray (peat FOAM, CDMX, Mexico) for 10 days in the vertical farm with a light intensity of 8500 lux provided by LED lamps (Venoya International Co., Lt, Hong Kong, China, Table 3) at a photoperiod of $18 / 6 \mathrm{~h}^{\mathrm{d}} \mathrm{d}^{-1}$. Eight seedlings per tray were transplanted at a density of $20 \times 20 \mathrm{~cm}$, where the crop was monitored for 30 days to complete a 40-day cycle.

Plant nutrition was carried out with a commercial nutrient solution for the production of leafy vegetables composed of a solution A with micronutrients and a solution $\mathrm{B}$ with micronutrients (table 2). For the first 10 days of sowing $2.5 \mathrm{~mL}$ of $\mathrm{A}$ and $\mathrm{B}$ were used per liter of water, after 10 days $5.0 \mathrm{~mL}$ of $\mathrm{A}$ and $\mathrm{B}$ were used. After transplanting, the nutrient solution was completely replaced every 10 days. The $\mathrm{pH}$ of the nutrient solution was maintained in the range of 5.5-6.5.
Table 2. Mineral composition of the nutrient solution.

\begin{tabular}{llll}
\hline Macronutrients & mg. $\mathrm{L}^{-1}$ & Micronutrients & $\mathrm{mg} \cdot \mathrm{L}^{-1}$ \\
\hline $\mathrm{N}$ & 180 & $\mathrm{Fe}$ & 1.5 \\
$\mathrm{P}$ & 41 & $\mathrm{Mn}$ & 0.7 \\
$\mathrm{~K}$ & 172 & $\mathrm{~B}$ & 0.13 \\
$\mathrm{Ca}$ & 158 & $\mathrm{Cu}$ & 0.06 \\
$\mathrm{Mg}$ & 25 & $\mathrm{Zn}$ & 0.14 \\
$\mathrm{~S}$ & 55 & $\mathrm{Mo}$ & 0.05 \\
\hline
\end{tabular}

Treatments and experimental design

After transplanting, the plants were subjected to a photoperiod of 18/6 h.d $\mathrm{d}^{-1}$ with three treatments of intensities and light spectrum according to commercial LED lamps in Mexico (table 3). The commercial lamps have a driver inside in order to connect them to the $127 \mathrm{~V}$ network, in the case of LED strips, they were connected to a $12 \mathrm{~V}$ and 20 A driver (TF12V10A, ÁguiLed, Mexico). A wattmeter (HER-432, Steren, Mexico) was used to measure the energy consumption of each treatment and the energy used to obtain 100 g.m${ }^{2}$ of fresh weight was estimated. All treatments were subjected to the temperature inside the building.

Table 3. Treatments to which the lettuce was subjected.

\begin{tabular}{|c|c|c|c|}
\hline Treatment & $\begin{array}{l}\text { Light } \\
\text { intensity } \\
\text { (lux) }\end{array}$ & Spectrum $^{2}$ & Illumination Type \\
\hline $\begin{array}{l}\text { T1-2100/ } \\
\text { RB }\end{array}$ & 2100 & $80 \% \mathrm{R}+20 \% \mathrm{~B}$ & $\begin{array}{l}\text { SMD5050 LED strips } \\
\text { (Corp. Res Electronics, } \\
\text { CDMX, Mexico) }\end{array}$ \\
\hline $\begin{array}{l}\text { T2-5700/ } \\
\text { RBIRUV }\end{array}$ & 5700 & $\begin{array}{l}71,6 \% \mathrm{R}+26.7 \% \\
\mathrm{~B}+0.85 \% \mathrm{IR}+ \\
0.85 \% \mathrm{UV}\end{array}$ & $\begin{array}{l}30 \times 30 \mathrm{~cm} \text { Lamp (Venoya } \\
\text { International Co., Lt, } \\
\text { Hong Kong, China) }\end{array}$ \\
\hline $\begin{array}{l}\text { T3-6300/ } \\
\text { RBWI- } \\
\text { RUV }\end{array}$ & 6300 & $\begin{array}{l}62.5 \% \mathrm{R}+25 \% \mathrm{~B} \\
+4.2 \% \mathrm{~W}+4.2 \% \\
\mathrm{IR}+4.2 \% \mathrm{UV}\end{array}$ & $\begin{array}{l}25 \times 25 \mathrm{~cm} \text { Lamp (ZGSG- } \\
\text { LLM, SUNPIN, United } \\
\text { States) }\end{array}$ \\
\hline
\end{tabular}

${ }^{1}$ Light intensity obtained with a BH1750 sensor with an accuracy of \pm 0.5 lx. ${ }^{2} \mathrm{R}=$ Red, $\mathrm{B}=\mathrm{Blue}, \mathrm{W}=$ White, $\mathrm{IR}=$ Infrared, and $\mathrm{UV}=$ Ultraviolet.

At the end of the crop cycle, 5 plants were randomly selected for each of the three treatments to measure fresh weight without the root. The fresh weight of each plant was measured using a balance (BAPRE-3, Rhino, CDMX, Mexico) with an accuracy of $0.2 \mathrm{~g}$.

Experimental results were subjected to a one-way analysis of variance (ANOVA) and a Duncan's multiple range test with a significance level of $\mathrm{p}=0.05$ using an algorithm developed in Python 3.4 (PSF, USA).

The temperature and humidity of the outside were taken from the automatic meteorological station of the National Water Commission (CONAGUA, Mexico) located in the facilities of the Mexican Institute of Water Technology (MTA. Jiutepec, Mor, Mex), which tracks meteorological variables (Temperature, Relative Humidity and Radiation). The data obtained both inside and outside were processed in a software developed in Python 3.4 (PSF, USA).

\section{Results and discussion}

Figure 2 shows the crop treatments and Figure 3 shows the variation in daily temperature and humidity inside and outside the building. Inside the average temperature remained at $25^{\circ} \mathrm{C}$ with a variation of $\pm 5{ }^{\circ} \mathrm{C}$ and the relative humidity also registered constant values of $60 \%$ with a variation of $\pm 10 \%$. The variables outside the 
house presented higher values and in the case of temperature, oscillations from 10 to $30^{\circ} \mathrm{C}$ were measured; relative humidity varied from 40 to $70 \%$. The relevance of the exterior is that a building with these characteristics in itself provides greater stability in the climate variables, in this case temperature and humidity.

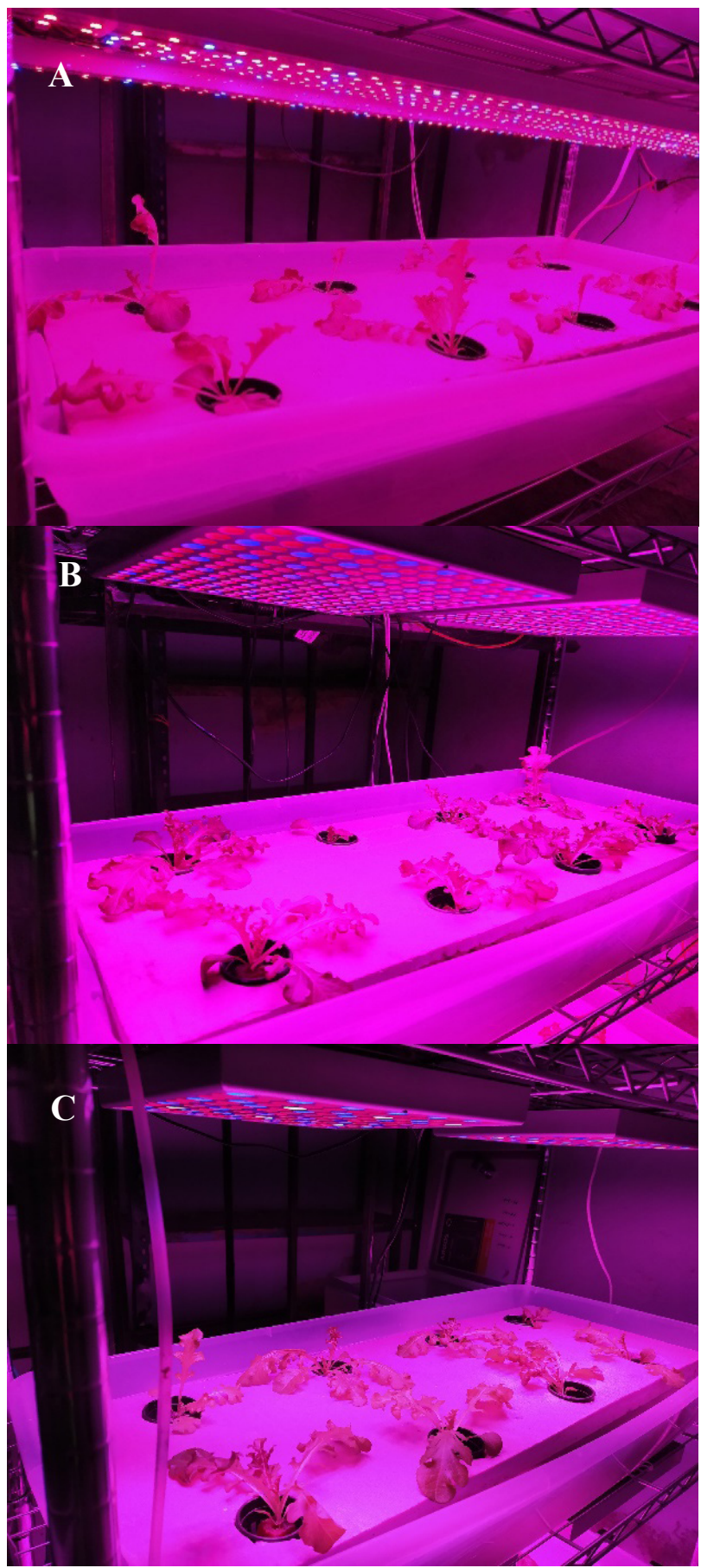

Figure 2. "Sangria" lettuce subjected to LED light. Three treatments with different intensity and light spectrum were used A) T1-2100/RB, B) T2-5700/RBIRUV and C) T3-6300/RBWIRUV.

The graphs show that the building is able to reduce the variation of the outside temperature in addition to conserving humidity which is a condition for crop development. It has been observed that the lack of total radiation and keeping the temperature constant at an average of $25^{\circ} \mathrm{C}$ outside the building, favored stem elongation and the development of looser heads (figure 3 ). Physiologically, the plant tries to capture more radiant energy and its geotropism indicates that it is in the upper part, hence its elongation, which is consistent with Al-Said et al. (2018) who found that when exposing lettuce to a temperature of $25^{\circ} \mathrm{C}$ and $28^{\circ} \mathrm{C}$, the exposed characteristics are presented.

A
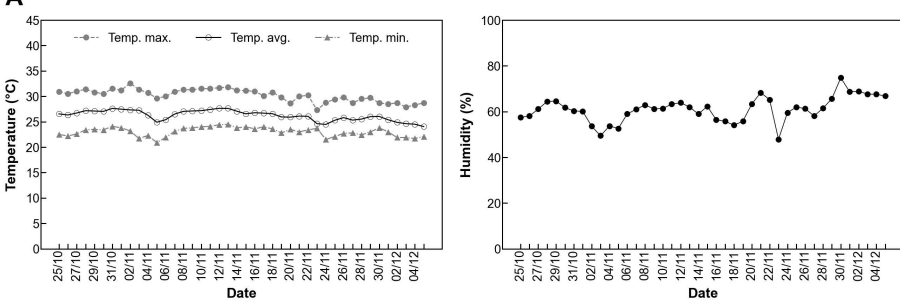

B
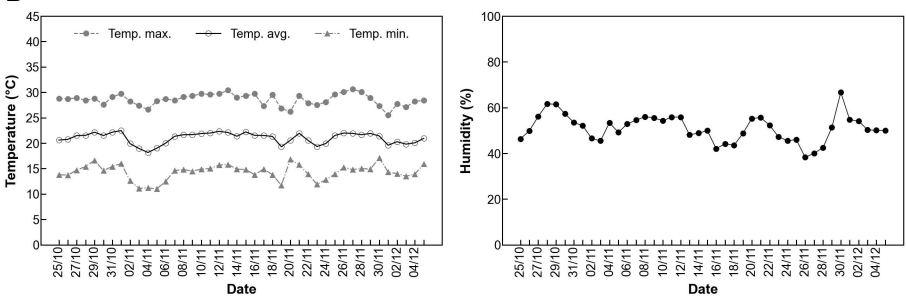

Figure 3. Temporal variation (from Oct 25 to Dec 4) of temperature and humidity inside (A) and outside (B) the building during the lettuce cycle (40 days).

The results shown in table 4, show that there are statistical differences between the agronomic characteristics measured for lettuce depending on the light intensity of each of the lamps and photoperiod to which each of the 3 treatments was subjected. Although it is true that the development of a crop is subjected to the interaction of climatic variables, with this experiment, it is intended to show that with conventional artificial lights it is possible to meet minimum requirements to obtain plants with characteristics similar to those obtained with specific lights in commercial plant factories.

Table 4. Effect of the intensity and spectrum of LED lights on the growth and development of lettuce.

\begin{tabular}{|c|c|c|c|c|c|}
\hline \multirow[b]{2}{*}{ Treatment } & \multirow[b]{2}{*}{$\begin{array}{l}\text { No. Of } \\
\text { leaves }\end{array}$} & \multirow{2}{*}{$\begin{array}{l}\text { Plant } \\
\text { height } \\
(\mathrm{cm})\end{array}$} & \multicolumn{2}{|c|}{ Leaf } & \multirow{2}{*}{$\begin{array}{c}\text { Fresh } \\
\text { weight } \\
\text { (g) }\end{array}$} \\
\hline & & & $\begin{array}{c}\text { Length } \\
(\mathrm{cm})\end{array}$ & $\begin{array}{l}\text { Width } \\
(\mathrm{cm})\end{array}$ & \\
\hline T1-2100/RB & $16.4 \pm 1.3 \mathrm{a}^{*}$ & $28.4 \pm 1.6 \mathrm{bc}$ & $19.1 \pm 1.0$ & $11.5 \pm 0.9 \mathrm{a}$ & $25.5 \pm 5.9 \mathrm{a}$ \\
\hline T2-5700/RBIRUV & $20.8 \pm 0.2 \mathrm{c}$ & $23.5 \pm 0.3 \mathrm{a}$ & $20.8 \pm 0.3$ & $15.8 \pm 0.2 \mathrm{bc}$ & $65.7 \pm 1.0 \mathrm{~b}$ \\
\hline T3-6300/RBWIRUV & $18.0 \pm 0.5 \mathrm{ab}$ & $27.8 \pm 0.7 \mathrm{~b}$ & $21.2 \pm 0.3$ & $15.5 \pm 0.6 \mathrm{~b}$ & $47.5 \pm 5.5 \mathrm{c}$ \\
\hline
\end{tabular}

* Data are mean values \pm ES of 5 plants per treatment. Different letters in the same column were significantly different by Duncan's multiple comparison method $(\mathrm{p} \leq 0.05)$

In addition to the fact that the lamps used in the present research provide low light intensity, it was observed that the exposure to red light (R:B 4:1) of T1-2100 treatment was correlated with stem elongation, these results are consistent to those obtained by Zhang et al. (2017) who report a higher height of lettuce when grown under red light in a R:B ratio 9:1 and 4:1. Hence the relevance of the combination of the other colors of the solar spectrum, depending on the type of plant, in this case lettuce. 


\section{5-5 |Rev. Fac. Agron. (LUZ). 2022, 39(1): e223920. January - March. ISSN 2477-9407.}

The measured plant parameters (height, weight, leaf size) were comparatively (among the three treatments) higher for the T2-5700 treatment (figure 4) whose spectrum is mainly composed of blue and red light with a 2.7:1 ratio. Zhang et al. (2018), found that quality characteristics were better for a suitable ratio of red and blue light at an R:B ratio 2.2:1 compared to white light.
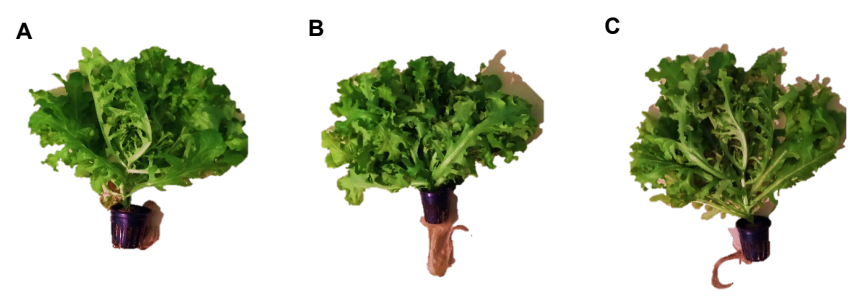

Figure 4. Effect of agronomic characteristics (size, shape) of the three treatments with different intensity and light spectrum, A) T1-2100, B) T2-5700 and C) T3-6300.

The width of leaves also presented a reduction in the size of the leaf, which is statistically significant due to the low illumination of the T1-2100 treatment, which improves with the other two light intensities T2-5700 and T-6300.

A higher light intensity increased plant growth, obtaining the maximum fresh weight of $65.7 \mathrm{~g}$ for an intensity of 5700 lux. This is consistent with Kang et al. (2013) who obtained higher fresh weight with higher light intensities where the maximum value was 81.28 g with $290 \mu \mathrm{mol} . \mathrm{m}^{-2} \mathrm{~s}^{-1}$ PPFD using a photoperiod of $18 / 6$ h.day $^{-1}$ and a R:B:W ratio 8:1:1. In another study carried out by Zhang et al. (2018) the highest fresh weight was obtained for an intensity of $250 \mu \mathrm{mol} . \mathrm{m}^{-2} \mathrm{~s}^{-1}$ PPFD which was $42.7 \mathrm{~g}$ with a photoperiod of 16/8 h.day ${ }^{-1}$ and a R:B ratio 2.2:1. Fresh weight of the T1-2200 treatment was significantly lower compared to the T2-5700 and T36300 treatments.

Due to the low yield and high power consumption of the driver used in the LED strips, the T1-2100 treatment is the least efficient for lettuce production and the most efficient is the T2-5700 treatment (table 5).

\section{Table 5. Energy consumption for LED light treatments on} lettuce.

Treatment Consumption (kwh per 100 g.m-2 of fresh weight)

\begin{tabular}{lc}
$\mathrm{T} 1-2100$ & 17.6 \\
$\mathrm{~T} 2-5700$ & 2.0 \\
$\mathrm{~T} 3-6300$ & 2.4 \\
\hline
\end{tabular}

With a light intensity of 2100 lux, the lettuce has an initial growth reaching a point where it stops and stops growing; these plants remained alive the rest of the time than the others, but no changes in size and weight were observed, so it is inferred that the amount of light provided by the used lamp is insufficient for it to perform its physiological functions and continue its development phases. An intensity of 5700 lux with an R:B ratio of 2.7:1 was the one that presented the highest fresh weight with the lowest electrical consumption and also fewer morphological problems were obtained. The highest fresh weight was related to a higher water consumption, which makes sense, the higher the evapotranspiration, the higher the dry matter production, even in indoor conditions.

\section{Conclusions}

The home plant factory implemented for lettuce production indoors in urban buildings is technically feasible. Among the basic requirements, it is concluded that commercial lamps with light intensities of 5700 lux and an R:B ratio of 2.7:1 achieve lettuce of $65.7 \mathrm{~g}$, which can be improved by extending the wavelength range (light quality).

\section{Literature cited}

Al-said, F., Hadley, P., Pearson, S., Kan, M. M. and iqbal, Q. (2018). Effect of high temperature and exposure duration on stem elongation of iceberg lettuce. Pakistan Journal of Agricultural Sciences, Faisalabad, Pakistan, 55(1), 95-101. https://doi.org/10.21162/PAKJAS/18.6554

Beacham, A. M., Vickers, L. H. and Monaghan, J. M. (2019). Vertical farming: a summary of approaches to growing skywards. The Journal of Horticultural Science and Biotechnology, 94(3), 277-283. https://doi.or $\mathrm{g} / 10.1080 / 14620316.2019 .1574214$

Benke, K., and Tomkins, B. (2017). Future food-production systems: Vertical farming and controlled-environment agriculture. Sustainability: Science, Practice and Policy, 13 (1): 13-26. https://doi.org/10.1080/15 487733.2017.1394054

de Anda, J., and Shear, H. (2017). Potential of vertical hydroponic agriculture in Mexico. Sustainability, 9(1), 1-17. https://doi.org/10.3390/su9010140

Eigenbrod, C. and Gruda, N. (2015). Urban vegetable for food security in cities. A review. Agronomy for Sustainable Development, 35, 483-498. https://doi.org/10.1007/s13593-014-0273-y

Kalantari, F., Tahir, O. M., Joni, R. A., and Fatemi, E. (2018). Opportunities and challenges in sustainability of vertical farming. J. Landsc. Ecol., 11, 35-60. https://doi.org/10.1515/jlecol-2017-0016

Kang, J. H., Krishna K. S., Sua A. S. L., Ryong J. B. and Jae H. S. (2013). Light intensity and photoperiod influence the growth and development of hydroponically grown leaf lettuce in a closed-type plant factory system. Horticulture, Environment, and Biotechnology, 54(6), 501-509. https:// doi.org/10.1007/s13580-013-0109-8

Loconsole, D., Cocetta, G., Santoro, P. and Ferrante, A. (2019). Optimization of LED lighting and quality evaluation of romaine lettuce grow in an innovative indoor cultivation system. Sustainability, 11(3): 841. http:// dx.doi.org/10.3390/su11030841

Organización para la Cooperación y el Desarrollo Económicos (OECD). (2012). Environmental Outlook to 2050: The Consequences of Inaction. Editorial OECD, https://doi.org/10.1787/9789264122246-en

Python Software Foundation (PSF), Python 3,4 (PSF, EUA). www. Phyton.org/

Pinstrup-Andersen, P. (2018). Is it time to take vertical indoor farming seriously? Global Food Security, 17, 233-235. https://doi.org/10.1016/j. gfs. 2017.09.002

Resh, M. H. (2013). Hydroponic food production: A definitive guidebook for the advances home gardener and the commercial hydroponic grower. CRC Press. https://doi.org/10.1201/b12500

Specht, K., Siebert, R., Hartmann, I., Freisinger, U. B., Sawicka, M., Werner, A., Thomaier, S., Henckel, D., Walk, H. and Dierich, A. (2014). Urban agriculture of the future: an overview of sustainability aspects of food production in and on buildings. Agric. Hum. Values, 31, 33-51. https:// doi.org/10.1007/s10460-013-9448-4

Wurr D. C. E., J. R. Fellows and A. J. Hambidge (1992). Environmental factors influencing head density and diameter of crisp lettuce cv. Saladin. Journal of horticultural science, 67(3), 395-401. https://doi.org/10.10 80/00221589.1992.11516264

Zhang, T., Shi, Y., Wang, Y., Liu, Y., Zhao, W., Piao, F. and Sun, Z. (2017). The effect of different spectral LED light son the phenotypics and physiological charactristics of lettuce (Lactuca sativa) at picking stage. Journal Biochemistry Biotechnology, 1(1), 14-19. https://doi. org/10.35841/BIOCHEMISTRY-BIOTECHNOLOGY.1.1.14-19

Zhang, X., He, D., Niu, G., Yan, Z. and Song, J. (2018). Effects of environment lighting on the growth, photosynthesis, and quality of hydroponic lettuce in a plant factory. International Journal of Agricultural and Biological Engineering, 11(2), 33-40. http://dx.doi.org/10.25165/j. ijabe.20181102.3420 